\title{
Assessing the Impact of Financial Support on Ghana's Agricultural Development
}

\author{
Isaac Atta Frimpong*, Hong Wei, Qibing Fan \\ Department of Economics, Yangtze University, Jingzhou, China \\ Email: iatta91@yahoo.com
}

How to cite this paper: Frimpong, I.A., Wei, H. and Fan, Q.B. (2022) Assessing the Impact of Financial Support on Ghana's Agricultural Development. Open Access Library Journal, 9: e7557. https://doi.org/10.4236/oalib.1107557

Received: May 25, 2021

Accepted: January 7, 2022

Published: January 10, 2022

Copyright $\odot 2022$ by author(s) and Open Access Library Inc.

This work is licensed under the Creative Commons Attribution International License (CC BY 4.0).

http://creativecommons.org/licenses/by/4.0/

(c) (i) Open Access

\begin{abstract}
Agriculture is a type of economic activity, livelihood, and provider of environmental services, contributing to the development process. It can participate, in concert with other sectors, in realizing faster growth, poverty reduction, and environmental sustainability. Agriculture has a special ability to reduce poverty. The objectives of the study are to identify agricultural development in Ghana and identify challenges of modern agricultural development in Ghana. Data from the field were collected from the primary and secondary sources. Depending on the resources available to the researcher, all the beneficiary farmers were interviewed to understand the situation on the ground to improve credit delivery and agriculture development in Ghana. It was identified that the several Rural Banks disburses the entire loan earmark for particular year to the farmers. However, the banks satisfy only 83.3 percent and 63.4 percent of the applicants in 2015 and 2016 financial years respectively. According to the project officers of the various rural banks, the reduction is due to low rate of recovery (i.e. 3.45) for the 2015 financial year. However, the farmers' complaint of late receipts of the loan and lack of storage facilities compelled them to sell the produce at uneconomic prices which led to low income, low investment and low savings. In 2019, it was recommended that the rural banks should take into account the advantages of providing credit in kind for purchased inputs. This would relieve the smallholder farmers of further transactions with which he may be unfamiliar and provide the bank with some assurances that the credit is used for the purposes intended. This credit must be timely as it will prevent the farmers from diversion and loss. Subjecting the problem to critical analysis, it is recommended that the economy and lifestyle of Ghana are dependent on agriculture. It is the major employer of her population and contributes massively to her foreign exchange, supplier of food and raw materials for the population and industries, provider of import substitution to solve the balance of payment situations in the country. However, the performance of this sector is inhibited by finance even though there is institutional source of credit from the com-
\end{abstract}


mercial and development banks; they are not readily made available to the small-scale farmers who produce the bulk of the country's food requirements.

\section{Subject Areas}

Business Analysis, Economic System, Environmental Economics

\section{Keywords}

Agricultural Development, Financial Institutions, Farm Size, Climate Change, Water Scarcity

\section{Introduction}

Agriculture is a type of economic activity, livelihood, and provider of environmental services, contributing to the development process. It can participate, in concert with other sectors, in realizing faster growth, poverty reduction, and environmental sustainability [1]. Agriculture has a special ability to reduce poverty. According to cross-country estimates, the effect of agricultural GDP growth on poverty reduction is at least twice as high as the effect of GDP growth coming from other sectors [2].

Estimates show that agriculture is the source of livelihood for $86 \%$ of rural people, and generates employment opportunities for 1.3 billion smallholders and landless workers [3]. How to use natural resources in the agricultural sector which is mostly improperly exploited can have negative or positive environmental outcomes: Groundwater depletion, agrochemical pollution, soil exhaustion, and climate change (through the contribution of $30 \%$ greenhouse gas emissions) versus environmental services, such as carbon sequestration, watershed management and biodiversity conservation [4].

Ghana's financial sector has gone through several reforms and liberalizations since 1988, with the key objective of improving the efficiency of financial resource mobilization and distribution to relevant growth sectors of the economy [5]. Until the reforms, credit and deposit functions of financial institutions in Ghana were deemed abysmal. Notably, there has been a poor allocation of financial credit to the agriculture sector [6]. Inclusive in the financial sector reforms in Ghana were rural and agriculture financing programmes such as the Rural Financial Services Projects. Though the agriculture sector received a lot of attention during the financial sector reforms, the fortunes of the sector in terms of its contribution to GDP have not seen much improvement for the past decade despite the fast-developing financial sector in Ghana. Since 2009, the sector's share of GDP has consistently declined from about $32 \%$ to $19 \%$ in 2015 [7]. Agriculture output growth recently declined from $5.7 \%$ in 2013 to a low of about $0.04 \%$ in 2015. The slowdown in agriculture output growth has mostly been influenced by the often-cited crop failures due to climate variability, lack of private sector and government investment support, low technological absorption, and financial 
constraints due to the perceived historic default credit risk in the sector [8].

\section{Problem Statement}

Nearly half the population of Ghana lives in rural areas, where agriculture is still the primary occupation of the economically active population [9]. This is despite claims of an expanding rural non-farm sector [10]. Even within the larger economy, the 2010 census estimates that agriculture remains the largest employment sector, offering jobs to about 41.6 percentage of the economically active population older than 15 years [9]. With poverty reduction being the core issue in Ghana's economic development, the sheer size of the agriculture sector means that one might expect it to play a lead role. Indeed, all of Ghana's policy blueprints since independence in 1957 have expected agriculture to drive economic growth and poverty reduction. Has agriculture lived up to its expected role? If not, is it a case of failure of agriculture? Or policy implementation or support from financial institutions? The agricultural transformation seems to be an inevitable stylized fact of development, characterized largely by major changes in agricultural land and especially labour productivity. It is the transition to a state of higher agricultural productivity, and the ensuing higher level of aggregate income, that creates finance needs, and the appropriate provision in both amounts as well as a form of finance can facilitate or delay the necessary transformation. Rural smallholders are the predominant agents of agricultural production in most low-income countries especially Ghana and are also the agents where the largest incidence of poverty and food insecurity is located. Rural smallholders have needs for similar types of financial services as urban-based agents, albeit the types of specific financial products needed are different given the agricultural production cycle. These include savings, loans, insurance, production and consumption risk management tools, payment systems, et cetera. Many rural residents and agricultural producers are constrained in their economic behaviour by the absence of many of these tools and are consequently greatly hampered in improving their livelihoods, thus affecting the overall growth and welfare of the countries where they reside. There exists a multitude of formal organizations that deliver financial services to rural residents, including commercial and publicly-owned banks and insurance companies, savings and loan cooperatives, microfinance banks, speciality financial institutions, such as leasing companies, housing and consumer finance companies. However, many of these institutions have not expanded much into agricultural finance. This is because of the dispersion of agricultural households that renders the provision of services expensive, the covariate risks, usually linked to weather, that affect large numbers of rural households simultaneously, lack of knowledge about the particulars of agriculture, and low education on the part of the rural service recipients. In their absence, a variety of informal financial institutions have tried to fill the gap. These include rotating savings and credit associations, local credit unions, financial NGOs, businesses financing their agricultural cus- 
tomers, local private moneylenders, friends and relatives, self-help groups, and many others. Nevertheless, a large number of rural smallholders in many low-income countries are underprovided in financial services and face high costs for the financial services available. Research has shown that the agriculture sector suffers from poor financial support. However, little research has explored why the contribution of financial institutions to the agricultural sector is very minimal. Thus, there is a knowledge gap in finance and agriculture sector growth. In this study, the focus is on the relationship between modern agricultural development and financial support.

The objectives of the study are to identify agricultural development in Ghana and identify challenges of modern agricultural development in Ghana.

\section{Literature Review}

\subsection{Background of Modern Agricultural Development in Africa}

Agriculture plays a key role in food security and economic development. However, most of the world's population in rural areas depends directly or indirectly on agriculture for their livelihoods. Yet as the world's population increases and migration to towns and cities intensifies, so the proportion of people not producing food will grow [11]. Agricultural development according to [12], is a multi-sectional activity that supports and promotes positive change in the rural and urban areas. However, the main objectives of agricultural development are the improvement of material and social welfare of the people. Therefore, agricultural development is seen as synonymous with rural development, the two terms are different but intrinsically related. Agricultural development is a part of rural development; rural areas cannot develop without agriculture being developed because about $90 \%$ of the rural dwellers are engaged in agricultural practices as their major source of income.

Ghana as a country seeks to become a leading economy in Africa and a major player in the world's economic and political affairs of which their 20-20-20 plan is their guideline. To become a developed nation, Ghana needs to speed up its economic growth by focusing on vital economic sectors like education, energy, agriculture and manufacturing. At this point in Ghana's development, the best approach is to focus on the agricultural sector. By focusing on agricultural development, Ghana can speed up its economic growth in the coming decade [13].

Agricultural development can also address gender disparities. In Sub-Saharan Africa and South Asia, women are vital contributors to farm work, but because they have less access to improved seeds, better techniques and technologies, and markets, yields on their plots are typically 20 to 40 percent lower than on plots farmed by men. Addressing this gap can help households become more productive and reduce malnutrition within poor families. Economic growth is seen as a long-term rises in the capacity to supply increasingly diverse economic goods to its population. It also entails a sustainable rise in national output with a manifestation of economic growth [14]. Therefore, the role of agriculture in trans- 
forming both the social and economic framework of an economy cannot be over-emphasized. It has been the source of gainful employment from which the nation can feed its teaming population, providing the nation's industries with local raw materials and as a reliable source of government revenue.

According to Adegoye \& Dittah in [14], a full developed economy, especially in agricultural sector, means an increase in the production of export crops with an improvement in the quantity and grades of such export crops. However, for a country to industrialize, agricultural output will be said to have acquired growth if agriculture can supply enough materials to agro-allied industries. In the light of this, Reynulds in [14] opined that agricultural development can promote economic development of underdeveloped countries in four different ways:

- By increasing the supply of food available for domestic consumption and release labour needed for industrial employment.

- By enlarging the size of the domestic market for the manufacturing sector.

- By increasing the supply of domestic saving.

- By providing foreign exchange earned by the agricultural exports.

Therefore, creating a sustainable agricultural development path means improving the quality of life in rural areas, ensuring enough food for present and future generations and generating sufficient income for farmers. Supporting sustainable agricultural development also involves ensuring and maintaining a productive capacity for the future and increasing productivity without damaging the environment or jeopardizing natural resources. Also besides, it requires respect for and recognition of local knowledge and local management of natural resources, and efforts to promote the capabilities of current generations without compromising the prospects of future ones. Consequently, economic and environmental sustainability, adequate farmers' income, productive capacity for the future, improved food security and social sustainability are important elements of developing countries' agricultural development [15]. Thus, when farmers grow more food and earn more income, they can feed their families, send their children to school, provide for their family's health, and invest in their farms and this makes their communities economically stronger and more stable for agricultural development.

\subsection{Financial Support for Agricultural Development in Africa}

There are two major types of finance for agricultural production and growth. First is medium and long-term finance for investment in both private capital as well as public capital. Second there is short-term finance for production or marketing. In this section we concentrate on finance for capital accumulation.

A recent State of Food and Agriculture report by the Food and Agriculture Organization [16] indicates that capital stock is directly related to agricultural GDP. The same report indicates the enormous difference in agricultural capital stock per worker among developed and low and middle-income countries. The ratio in 2005-07 was almost 35:1. 
More worryingly the growth rate of agricultural capital stock per worker in developing countries has declined over the past 30 years, compared to a significant increase for developed countries. The decline is large and significant in Sub-Saharan Africa and insignificant in South Asia, while in all other regions the agricultural capital stock per worker has increased. [16] suggests that the level of per worker agricultural capital stock is directly related to the level of agricultural public expenditure per worker. This makes for a direct link between agricultural public expenditures and agricultural capital stock. However, not all public expenditure in agriculture is investment. The share of investment in agricultural public expenditures varies from 9 to 84 percent as per a review of relevant figures by [16].

Concerning public expenditures for agriculture, [16] reports that while total public expenditures have increased world-wide in absolute terms, but mostly in the East Asia and Pacific and Latin America regions, the share of public expenditures going to agriculture has declined over time. Moreover, within that declining share, the share of agricultural GDP going to research and development, a major determinant of agricultural productivity growth, has stayed the same in lowland middle-income countries at 0.54 percent, while the share in high income countries has increased from 1.53 percent in 1980 to 2.37 percent in 2000 [16]. The food crisis of 2006-8 may have changed these trends but no aggregate figures are available.

The financing needs of agriculture to achieve a world free of hunger by 2025 have been estimated by [17] who provide estimates of incremental public expenditures on agriculture and safety nets needed. Over this period, incremental annual public expenditures are US $\$ 50.2$ billion. Of these the bulk ( 18.5 billion US $\$$ or almost 40 percent) is for expansion of rural infrastructure and market access, 9.4 billion is for conservation of natural resources, 6.3 billion is for research and development and extension, 5.6 billion for rural institutions and 10.4 billion for safety nets. They also estimate the average total (public and private) annual investments (not only incremental) needs of agriculture in low- and middle-income countries for the period up to 2050 to reach the FAO long term projections for food and agriculture that are consistent with global food adequacy. The investment needs are considerable amounting to more than 200 billion constant 2009 USD annually.

Concerning resource flows into agriculture, [18] have made a review of all the available information sources on this and have arrived at some general findings. Comparing among datasets, the average spending on and investment in agriculture for low and middle income countries for the three most recent years for which data is available reveals that:

- Government annual spending on agriculture (both current and investment) in low and middle income countries averaged 160 billion USD dollars in 2005-2007.

- Foreign Direct Investment (FDI) inflows to the above countries averaged 3 billion current dollars (2006-2008) to agriculture, forestry, fisheries and 
hunting.

- Official Development Assistance (ODA) to agriculture averaged 7 billion constant 2005 dollars during 2007-2009.

- All flows exhibited an increase in total levels as well as levels per agricultural worker, since at least the early 2000s.

- Levels of FDI were larger for the high income country group than for the low and middle income country groups.

The above numbers suggest that annual investment flows into agriculture are much smaller than what is needed to achieve a world free of hunger. Among these flows, ODA to agriculture decreased from the 1980s to 2004 and from then on has increased considerably. Furthermore, the composition of aid to agriculture from 2000 to 2008 reveals that the bulk of aid to agriculture (more than a quarter) has gone into agricultural policy and administration management. Food production and extension, while small in the early 2000s, have seen a revival in the later years. Concerning FDI flows into agriculture, [19] have reviewed available figures on this and showed that much of the apparent upward trend in total FDI is in reality due to an increase in the number of countries receiving FDI that are included in the dataset (from about 30 to 70), and because the data are reported in current dollar values, rather than constant dollar values. They also showed that FDI inflows to food and beverages are much larger than inflows of FDI to agriculture.

\subsection{Theoretical Framework of Financial Support for Agricultural Development}

\subsubsection{Trade-Off Theory of Capital Structure}

Trade-off capital structure concept is proposed by [20]. They conclude on the premise that a business decides how much debt financing and how much equity financing to use by weighing the costs and benefits they found a compromise between bankruptcy's dead-weight effects and money-saving benefits. An essential theoretical aim is to explain the fact that farming can be partly funded by debt and partly by capital. The principle notes that debt financing, debt tax incentives and debt finance costs, economic risk expenses like debt default costs and non-bankruptcy costs are advantageous (e.g. staff leaving, suppliers demanding disadvantageous payment terms and bondholder/stockholder infighting). When the debt level reaches a certain level the increase in the cost of equity will be higher than the reduction from the tax shield due to the increased risk of default on the debt payments [21].

\subsubsection{Net Income Approach to Capital Structure Theory}

The Net Income Approach to Capital Structure Theory was proposed by [22]. He postulated that a rise in financial leverage would lead to a change in the cost of capital. In other terms, if the debt ratio rises, capital structure improves and the weighted average cost of capital (WACC) reduces, leading to a higher company price. The hypothesis suggests that agriculture could increase its value and 
reduce overall capital costs by increasing the debt level in its capital structure, contributing to increased productivity in agriculture.

\subsubsection{Theory of Finance and Growth}

The theory of finance and growth was introduced by [23]. He argues that financial intermediation plays an important role in economic growth through the banking network. Schumpeter's main argument is whether finance leads to the development of other economic sectors that include manufacturing, and he claims that banking institutions support financial companies more. Consequently, the financial institution has a dual impact on economic sector production, which includes the agricultural sector. [24] first stresses the former influence, which also finds a positive correlation between financial growth and the actual per capital GNP rate. The theory therefore emphasizes the function of the financial system in the development of agriculture, especially in developing countries, since the nation with a well-funded financial system will support economic growth.

\subsection{Challenges of Modern Agricultural Development in Ghana}

Agriculture contributes a significant share to the SSA economy and the majority of the population depends on this sector as their primary source of livelihood. According to the Food and Agriculture Organization of the United Nations, more than half (57\%) of the Sub-Saharan African population relies directly on agriculture. Improvement in agricultural productivity could reduce rural poverty by ensuring a sustainable supply of food, reducing food prices, generating export earnings and higher income for farmers, increasing on-farm employment and farm wage rates, and by creating linkages between farming and other sectors that are drivers of the rural economy and provide capital and labor for growth in other sectors of the economy. In addition, improved agricultural productivity can support human capital development through investments for better nutrition, health, and education [25]. A sustainable supply of a variety of foods as a result of agricultural growth could enhance productivity of individual lives and collectively of the national economy and social wellbeing [26]. Agricultural development and food systems in Sub-Saharan African countries face considerable challenges. While the world population is projected to reach 9.7 billion by 2050 , more than $50 \%$ of this increase is expected to come from Africa, an increasingly significant driver of food demand. However, the potential of African agriculture to satisfy a growing food demand in response to the population increase is constrained by several factors. Africa is experiencing a decline of farm size mainly due to agricultural population increase, traditional land inheritance customs and to rapid urbanization which stimulates crop land conversion for expansion of urban residency, industry, roads and other infrastructure [27] [28]). Additionally, climate change is a global phenomenon that affects agricultural productivity in every corner of the world by causing variable weather conditions, more intense weather events, drought, and alterations in diseases and pests; however, the 
extent of its adversity depends on adaptive capabilities of farmers [29]. For example, projections suggest that in Sub-Saharan Africa, a temperature increase by $1^{\circ} \mathrm{C}$ can cause a significant revenue decline to dry land crops ( $\$ 27$ per hectare) and livestock ( $\$ 379$ per farm), but an increase in revenue from irrigated crops (\$30 per hectare) [30]. Thus, in response to temperature increase, irrigated agriculture clearly buffers the revenue loss due to dry land agriculture productivity decline. However, irrigation requires considerable capital investment that a majority of African farmers cannot afford. An increasing demand for agricultural products in the supply chain is a key driver for productivity growth, agricultural transformation, and increasing household income. Despite increased retailing through supermarkets in a few countries in Africa, farmers' market participation is still constrained by food safety standards, poor infrastructure, weak agricultural institutions, and high transaction costs [31]. Despite the challenges facing African agriculture, initiatives tailored to encourage investment in domestic agriculture are emerging. African governments are reshaping yield-focused agricultural policies to nutrition-sensitive agriculture with public health promotion components. Considering that a high portion of the projected increase in world population by 2050 is expected to come from Sub-Saharan Africa, origination of this growth in a limited-resource setting could be considered a risk for development. However, unlike other parts of the world where the population transition has already occurred, Sub-Saharan African countries are at the early stage of population transition. The demographic structure is characterized by a high proportion of the population at economically favourable ages. For example, during 2015 the working age ( 25 - 64 years) group reached $36.2 \%$ of the population and is growing more rapidly than in other parts of the world [32]. The estimated demographic dividend in Sub-Saharan Africa could reach 11\% - 15\% of the GDP growth by 2030 and contribute to 40 - 60 million fewer poor during the same period [33]. Sub-Saharan Africa countries are experiencing rapid urbanization and income growth. Urbanization and income growth are again accompanied by changes in dietary patterns. For example, in Asia in response to income increments, consumption has shifted from rice to wheat and then to livestock [34]. In addition, urbanization and increase in income give rise to higher per capita consumption of animal source foods which stimulates growth in the livestock sector [35]. People will follow healthier eating styles such as increasing consumption of fruits and vegetables. Furthermore, trends and total expenditure for consumption of food away from home will increase [36]. These scenarios will create demand for the agricultural sector to increase production of a large volume of diversified food crops and animal source foods which again will support expansion of modern supermarkets and development of restaurants. On the other hand, urbanization and income growth could result in a shift in dietary habits to a typical "western diet" characterized by greater inclusion of processed foods, meat and more fat and sugar which are linked to the development of chronic diseases [37]. This dietary transition is occurring in developing coun- 
tries, thus posing the joint challenges of both under and over nutrition [38]. The cost of over nutrition is not insignificant. For example, medical and economic costs of obesity in the US for the year 2014 were estimated to be \$1.4 trillion. Similarly, in developing countries non-communicable disease contributes to $33 \%$ of disability adjusted life years (DALYS) and this percentage is projected to increase to $45 \%$ in the year 2030 [39].

\subsubsection{Farm Size Decline}

Since the mid-1990's, agricultural production worldwide has shown dramatic increases in yields resulting in a significant decrease in the proportion of hungry people. These increases are attributed to several factors such as the use of improved agricultural inputs, the discovery of high-yield and pest-resistant varieties, and the use of labour-saving mechanizations. However, the increase in agricultural production in Africa mainly has come from the expansion of farm land. About $52 \%$ of the world's arable land is in Africa. However, there has been a higher rate of growth in the agricultural population than in the expansion of cultivated land [27]. Population is a threat to agricultural development by causing increased demand for land as well as cropland conversion for urban expansion, industry, roads and other infrastructure at the expense of the arable land. The estimated loss of crop land due to conversion into spaces for non-agricultural purposes in developing countries will reach 30 - 60 million hectares by the year 2030 [28]. FAO data from 1960 to 2000 show that while cultivated land in Sub-Saharan Africa only increased marginally, the agricultural labour force increased dramatically resulting in a steady decline in the ratio of cultivated land to agricultural population from shrinkage in farm size. The trend is especially high for Ethiopia and Kenya with dense rural populations. Moreover, as agriculture productivity is strongly associated with land distribution, variation in land access among farmers is also an important factor to consider for agricultural growth. In general, land distribution in Africa is highly unbalanced. An average landholding in six countries (Ethiopia, Kenya, Mozambique, Rwanda, Zambia and Zimbabwe) during the year 2000 was in the range of 0.56 hectares per person in Zambia to 0.16 hectares per person in Rwanda. Compared to average landholdings by households in the lower quartile, those in the highest quartile controlled eight to twenty times more land. Country specific data analysis showed that, in Kenya, the mean land holdings by household at the lower and higher quartiles were 0.08 vs. 1.10 hectares per capita. Similarly, in Ethiopia and Rwanda per capita land access for those in the lowest quartile was less than 0.03 hectares [27]. This condition affects the viability of the smallholder farmers and the agricultural system in the region, in general, by constraining use of new agricultural technology and inputs, and limiting agricultural commercialization and revenues from crop sales [27].

\subsubsection{Climate Change}

Climate changes exert adverse effects on agricultural productivity through a 
wide range of meteorological and hydrological processes, including increases in the atmospheric temperature affecting rate of precipitation and evaporation resulting in water scarcity, lack of predictability of weather events such as the "seasonal" rains that require smallholders to plan cultivation, and by causing greater frequency of extreme weather events that can cause great soil and crop losses. Climate change can also affect agricultural productivity indirectly through elevating reproduction rate and movement patterns of pests. Moreover, a rise in temperature or drought affects the resistance of crops to disease [29]. Climatic condition changes stimulate development of adaptive responses such as adjustments to the farming system to prevent productivity losses. It is assumed that moderate changes to farming systems due to climatic changes can be adapted by farmers. Nevertheless, this resilience could reach its limit of effectiveness as severity of the change in climatic condition increases; these changes create risks that may overwhelm the resilience of resource-poor African farmers [40]. A panel analysis of crop production and weather data to estimate yield response to climatic change reported that by 2050, the mean production changes in Sub-Saharan Africa are estimated to be $-22 \%$ for maize, $-17 \%$ for millet, $-17 \%$ for sorghum, and $-18 \%$ for groundnuts. However, a change of only $-8 \%$ was estimated for cassava [41]. A report on future prospects for cereal production from rain-fed agriculture showed that by 2025, the annual cereal deficit for Sub-Saharan Africa would reach 35 million tons compared to 9 million tons during 2000, putting Africa as a net importer of cereal [42]. Such predictions illustrate the need to develop robust adaptive mechanisms, create supportive policies that help farmers deal with risk and build agricultural support systems to develop local food systems that function in such an environment.

\subsubsection{Water Scarcity}

Water is a critical driver of agricultural production. Agricultural activities such as crop and livestock production, fishing and agro-processing are directly influenced by the availability of quality water. Scarcity of water can cause significant threats to the smallholder farming society of Sub-Saharan Africa by adversely affecting yields [43]. Globally, by the year 2050, it is predicted that about $66 \%$ of the world population will be vulnerable to water shortages. Such shortages will have a strong impact on food production because agriculture uses a large proportion of the fresh water and Sub-Saharan Africa will be among the most affected regions [44]. Half of the land in Sub-Saharan Africa is arid and semi-arid characterized by limited precipitation with a high rate of evaporation. Yet, a large percentage of the population in the region relies on rain-fed agriculture which is the source of about $90 \%$ of the staple food. In addition, livestock production, which again is vulnerable to an increasingly variable precipitation, is among the main economic sources in Sub-Saharan Africa [45]. By the year 2025, 22 of 28 countries in Sub-Saharan Africa could face water scarcity. In addition, it is estimated that even before the onset of 2050 , per capita water availability will be reduced below the basic requirement $\left(1000 \mathrm{~m}^{3} / \mathrm{capita} / \mathrm{year}\right)$ in Eastern and 
Southern Africa countries and will be in the range of $1000-2000 \mathrm{~m}^{3} / \mathrm{capita} /$ year for West African countries [46]. In 2017, the fourth regional assessment report of the Intergovernmental Panel on Climate Change (IPCC), projected that by 2020, potential yield from rain-fed agriculture in some African countries could be reduced by up to $50 \%$ due to climate change. In addition, it was estimated that 75 - 250 million people would be exposed to scarcity of water. They further projected that due to a rise in water temperature, fishing would be compromised. Although the potential impact of climate change on agricultural productivity can be reduced substantially by putting adaptive mechanisms in place, the cost of coping with variable weather conditions and adaptation to climatic changes could be more than 5\% - 10\% of the Gross Domestic Product (GDP). In addition to the expected impact of climate change, the increasing population growth coupled with climate change could further intensify water scarcity [45].

\subsection{The Effects of Agriculture Development on Ghana's Economy}

The important role agriculture plays in economic development, particularly of low-income countries such as Ghana, cannot be over-emphasised. Developments in the global food market over the past decade have accentuated this reality. It is rare, if not impossible, for an agricultural economy such as that of Ghana to experience pro-poor industrial growth without the emergence of a productive agriculture sector [47]. The sector maintains its traditional role of making major contributions to GDP, employment, food security, and foreign exchange earnings. The sector also contributes to social stabilisation, provides a buffer during economic shocks and also contributes to cultural values associated with farming [48].

Given its large share in national output and significant contribution to other growth indicators, agriculture is seen as the engine of economic growth. From simulation analysis, agriculture sector-led growth has been shown to be more effective in reducing poverty both at the national level and particularly in poor regions because of its strong income and consumption linkages [49].

Ghana for many years had a particularly high share of agriculture in total GDP compared with other Africa countries and the sub-Saharan Africa average. There has been some discussion in recent times about the economy of Ghana beginning to show signs of structural change due to the decline in agriculture's contribution to GDP. This is because:

- As economies grow there is decreasing demand for food compared with other commodities;

- The use of advanced production technologies, which raises output per factor input. It is, however, doubtful that Ghana has to any significant extent experienced these factors. Agricultural production methods, for example, are still very rudimentary.

Agriculture provides employment for a substantial proportion of the population, particularly in rural areas but with an overall decline over time. From 
1984-2000 the population employed in agriculture declined at an annual average rate of about 0.6 percent compared with about 0.8 percent per year over the period 2000-2010. The 2000 Population and Housing Census put the economically active population employed in agriculture at 50.3 percent. The 2010 census results show that although agriculture remains the single largest employer of labour in Ghana, its share of employed people has declined to about 42 percent. There has been massive rural-urban migration, with labour movement out of agriculture into other sectors of the economy, as predicted by economic theory. There are, however, important spatial variations. The northern regions of the country have significantly larger shares of their populations (69 percent - 73 percent) engaged in agriculture than other regions.

Agriculture is a major foreign exchange earner, contributing an annual average of about 40 percent of all export revenue over the period 1997-2011. This is in spite of the country's vast mineral and other natural resource endowments. Indeed, the sector's foreign exchange contribution was as high as 52.8 percent in 2004 but has since been declining gradually, recording 25.5 percent in 2011. A substantial proportion (60 percent - 87 percent) of these earnings is from cocoa. Efforts have been made, through policies, projects and programmes, to diversify Ghana's exports and thus reduce overreliance on cocoa as the major agricultural export earner. Consequently, non-traditional agricultural export earnings have risen from an average of about US $\$ 69$ million per year over the period 1996-2000 to an average of about US \$165 per year over the period 2001-2011. Nevertheless, these barely make up an average of 10 percent of all agricultural export earnings. Aside from the above traditional roles, agriculture also enhances social viability through population movements between agriculture and other sectors, and through rural-urban migration. In Ghana, the contribution of agriculture to national social viability has been low because of slow structural transformation of the sector. The social viability role has been evident primarily in agricultural population redistribution as farmers' chase emerging opportunities across ecological zones. This makes agriculture policy an intrinsic part of broader national policy, the effective implementation of which can lead to sustainable growth in incomes and poverty reduction.

\section{Discussion}

Data from the field were collected from the primary and secondary sources. Depending on the resources available to the researcher, all the beneficiary farmers were interviewed to understand the situation on the ground to improve credit delivery and agriculture development in Ghana.

\subsection{Findings}

It was identified that the several Rural Banks disburses the entire loan earmark for particular year to the farmers. However, the banks satisfy only 83.3 percent and 63.4 percent of the applicants in 2015 and 2016 financial years respectively. 
According to the project officers of the various rural banks, the reduction is due to low rate of recovery (i.e. 3.45) for the 2015 financial year. However, the farmers' complaint of late receipts of the loan and lack of storage facilities compelled them to sell the produce at uneconomic prices which led to low income, low investment and low savings.

The study also revealed that the loans are inadequate to meet the production cost of the farmers. The inadequacy of the loan according to the Project officer is due to the regulation of the Bank of Ghana to grant 38 percent of the total deposit as loan and use 52 percent of the deposits to buy government shares and bonds and the 10 percent for reserves.

\subsection{Recommendations}

The banks are advised to learn from the operations of the various commercial Banks and allow the farmers to use their farms as collateral to access the loan and pay it at the end of every crop season. The banks should provide the farmers with storage facilities if affordable to store the produce to attract high prices in the market before selling them. Should it be expensive, the bank should buy the produce farmers and store them for sale when the produce attracts high prices.

In 2019, it was recommended that the rural banks should take into account the advantages of providing credit in kind for purchased inputs. This would relieve the smallholder farmers of further transactions with which he may be unfamiliar and provide the bank with some assurances that the credit is used for the purposes intended. This credit must be timely as it will prevent the farmers from diversion and loss.

Subjecting the problem to critical analysis, it is recommended that the economy and lifestyle of Ghana are dependent on agriculture. It is the major employer of her population and contributes massively to her foreign exchange, supplier of food and raw materials for the population and industries, provider of import substitution to solve the balance of payment situations in the country. However, the performance of this sector is inhibited by finance even though there is institutional source of credit from the commercial and development banks; they are not readily made available to the small-scale farmers who produce the bulk of the country's food requirements.

\section{Acknowledgements}

I would love to reveal my unique thanks of gratefulness to my supervisor Professor Wei Hong as well as my associate Professor Fan Qibing who gave me the golden chance to write this article on the topic of assessing the impact of financial support on Ghana's agricultural development. I also desire to express my thankfulness to my schoolmates for their assistance as well as guidance.

I would likewise such as to express my special many thanks of gratitude to my relatives Rev.Fr. Dominic Agyapong, Mrs. Veronica Adu Brobbey, Seth Osei Sarpong, Emmanuel Oppong and friends Adu Kumi and Randy Amponsah whose passion in my write-up was very helpful. 


\section{Conflicts of Interest}

The authors declare no conflicts of interest.

\section{References}

[1] Ligon, E. and Sadoulet, E. (2017) Estimating the Relative Benefits of Agricultural Growth on the Distribution of Expenditures. World Development, 109, 417-428. https://doi.org/10.1016/j.worlddev.2016.12.007

[2] Christiaensen, G., et al. (2019) Open Science Practices Are on the Rise: The State of Social Science (3S) Survey. https://doi.org/10.31222/osf.io/5rksu

[3] Jacobson, A., Lam, L., Rajendram, M., et al. (2018) A Gut Commensal-Produced Metabolite Mediates Colonization Resistance to Salmonella Infection. Cell Host \& Microbe, 24, 296-307. https://doi.org/10.1016/j.chom.2018.07.002

[4] Talukder, B. and Blay-Palmer, A. (2017) Comparison of Methods to Assess Agricultural Sustainability. In: Lichtfouse, E., Ed., Sustainable Agriculture Reviews, Springer, Cham, 149-168. https://doi.org/10.1007/978-3-319-58679-3_5

[5] Aryeetey, E., Nissanke, M., and Steel, W.F. (2000) Intervention and Liberalization: Changing Policies and Performance in the Financial Sector. In: Aryeetey, E., Harrigane, J. and Nissanke, M., Eds., Economic Reforms in Ghana: The Miracle and the Mirage, James Currey and Woeli Publishers, Oxford.

[6] Quartey, P., et al. (2012) Agricultural Financing and Credit Constraints: The Role of Middlemen in Marketing and Credit Outcomes in Ghana. Institute of Statistical, Social and Economic Research, University of Ghana, Accra.

[7] Ghana Statistical Services (GSS) (2016) 2015 Labour Force Report. Ghana Statistical Service, Accra. http://www.statsghana.gov.gh/

[8] Oteng-Abayie, E.F., Yusif, H. and Abdul-Aziz, U.A. (2012) Empirical Evidence on Financial Development and Agriculture Output Growth in Ghana. Department of Economics, Kwame Nkrumah University of Science and Technology, Accra. https://www.researchgate.net/profile/Eric-Fosu-Oteng-Abayie/publication/334599978

[9] Ghana Statistical Service (2012) 2010 Population and Housing Census: Summary Report of Final Results.

[10] Hilson, G. and Garforth, C. (2015) 'Agricultural Poverty' and the Expansion of Artisanal Mining in Sub-Saharan Africa: Experiences from Southwest Mali and Southeast Ghana. Population Research and Policy Review, 31, 435-464. https://doi.org/10.1007/s11113-012-9229-6

[11] Cardno (2017) Agricultural Development as a Key Role in Food Security and Economic Development in Most of the World's Population in Rural Area.

[12] Nwachukwu, I. (2018) Planning and Evaluation of Agricultural and Rural Development Project. Lambhouse Publishers, Rye, 6 p.

[13] Agbugba, I., Kelechi, I. and Ebitari, B. (2018) A Comparative Study of the Agriculture Sector Contribution to the Economic Growth of Nigeria and Malaysia. IOSR-Journal of Agriculture and Veterinary Science, 2, 18-21.

[14] Oyeyipo Eyitayo, J., et al. (2013) Poverty: Place of Agricultural Development on Economic Growth of Nigeria. International Journal of Research and Innovation in Social Science, 5, 511-519.

[15] Ludlow, P. (2018) The European Commission. In: Keohane, R.O. and Hoffmann, S., Eds., The New European Community, Routledge, New York, 85-132.

https://doi.org/10.4324/9780429496189-3 
[16] FAO, IFAD and WFP (2015) The State of Food Insecurity in the World 2015. Meeting the 2015 International Hunger Targets: Taking Stock of Uneven Progress. FAO, Rome.

[17] Mundlak, Y. (2019) Elmhirst Memorial Lecture: The Dynamics of Agriculture. In: Peters, G.H. and von Braun, J., Food Security, Diversification, and Resource Management: Refocusing the Role of Agriculture, Routledge, London, 18-48. https://doi.org/10.4324/9780429457326-2

[18] McCullough, E.B., Pingali, P.L. and Stamoulis, K.G. (2019) The Transformation of Agri-Food Systems: Globalization, Supply Chains and Smallholder Farmers. FAO and Earth Scan, Rome.

[19] Karlan, D. and Morduch, J. (2018) Access to Finance. In: Rodrik, D. and Rosenzweig, M.R., Handbook of Development Economics, Elsevier, Amsterdam, 4703-4784.

[20] Kraus, A. and Litzenberger, R.H. (1973) A State-Reference Model of Optimal Financial Leverage. The Journal of Finance, 28, 911-922.

https://doi.org/10.1111/j.1540-6261.1973.tb01415.x

[21] Malm, S. and Roslund, E. (2013) The Bond-to-Total Debt Ratio and Its Impact on Firms' Performance. Master Thesis, Umea University, Sweden.

[22] Durand, D. (1952) Cost of Debt and Equity funds for Business Trends and Problems of Measurement. Conference on Research in Business Finance, National Bureau of Economic Research, Inc., Cambridge, 215-262.

[23] King, R.G. and Levine, R. (1911) Finance and Growth: Schumpeter Might Be Right. The Quarterly Journal of Economics, 108, 717-737. https://doi.org/10.2307/2118406

[24] Townsend, R.M. (1969) Financial Structure and Economic Activity. The American Economic Review, 73, 895-911.

[25] Irz, X., Lin, L., Thirtle, C. and Wiggins, S. (2019) Agricultural Productivity Growth and Poverty Alleviation. Development Policy Review, 19, 449-466. https://doi.org/10.1111/1467-7679.00144

[26] Demment, M.W., Young, M.M. and Sensenig, R.L. (2018) Providing Micronutrients through Food-Based Solutions: A Key to Human and National Development. The Journal of Nutrition, 133, 3879S-3885S. https://doi.org/10.1093/jn/133.11.3879S

[27] Jayne, T.S., Kabaghe, C. and Minde, I. (2017) Enhancing United States Efforts to Develop Sustainable Agri-Food Systems in Africa. The Farm Journal Foundation.

[28] Döös, B.R. (2017) Population Growth and Loss of Arable Land. Global Environmental Change, 12, 303-311. https://doi.org/10.1016/S0959-3780(02)00043-2

[29] Gornall, J., Betts, R., Burke, E., Clark, R., Camp, J., Willett, K. and Wiltshire, A. (2020) Implications of Climate Change for Agricultural Productivity in the Early Twenty-First Century. Philosophical Transactions of the Royal Society of London. Series B, Biological Sciences, 365, 2973-2989.

[30] Kurukulasuriya, P., Mendelsohn, R., Hassan, R., Benhin, J., Deressa, T., Diop, M., et al. (2016) Will African Agriculture Survives Climate Change? The World Bank Economic Review, 20, 367-388. https://doi.org/10.1093/wber/lhl004

[31] Gashu, D., Demment, M.W. and Stoecker, B.J. (2019) Challenges and Opportunities to the African Agriculture and Food Systems. African Journal of Food, Agriculture, Nutrition and Development, 19, 14190-14217. https://doi.org/10.18697/ajfand.84.BLFB2000

[32] UNECA (2016) Urbanization and the Quality of Growth in Africa. In: Manuh, T. and Yemeru, E.A., Eds., The Quality of Growth in Africa, Columbia University Press, New York, 375-397.

[33] Ahmed, S.A., et al. (2016) How Significant Is Sub-Saharan Africa's Demographic 
Dividend for Its Future Growth and Poverty Reduction? Review of Development Economics, 20, 762-793. https://doi.org/10.1111/rode.12227

[34] Patel, S., et al. (2018) Socio-Economic Impacts of Climate Change. In: Kumar, P., et al., Eds., Climate Impacts on Sustainable Natural Resource Management, John Wiley \& Sons, Hoboken, 237-267.

[35] Bachewe, F., Minten, B. and Yimer, F. (2017) The Rising Costs of Animal-Source Foods in Ethiopia: Evidence and Implications. International Food Policy Research Institute (IFPRI).

[36] Ma, H.Y., Huang, J.K., Fuller, F. and Rozelle, S. (2016) Getting Rich and Eating out: Consumption of Food away from Home in Urban China. Canadian Journal of Agricultural Economics, 54, 101-119. https://doi.org/10.1111/j.1744-7976.2006.00040.x

[37] Pettigrew, S.M., Pan, W.K., Berky, A., Harrington, J., Bobb, J.F. and Feingold, B.J. (2019) Adoption of a Western Diet Is Inversely Associated with Selenium Intake. Science of the Total Environment, 687, 1046-1054. https://doi.org/10.1016/j.scitotenv.2019.05.484

[38] Abdullah, A. (2015) The Double Burden of Undernutrition and Overnutrition in Developing Countries: An Update. Current Obesity Reports, 4, 337-349. https://doi.org/10.1007/s13679-015-0170-y

[39] Bygbjerg, I.C. (2018) Double Burden of Non-Communicable and Infectious Diseases in Developing Countries. Science, 337, 1499-1501.

https://doi.org/10.1126/science.1223466

[40] Howden, S.M., Soussana, J.F., Tubiello, F.N., Chhetri, N., Dunlop, M. and Meinke, H. (2018) Adapting Agriculture to Climate Change. Proceedings of the National Academy of Sciences of the United States of America, 104, 19691-19696. https://doi.org/10.1073/pnas.0701890104

[41] Smith, V., De Pinto, A. and Robertson, R. (2019) The Role of Risk in the Context of Climate Change, Land Use Choices and Crop Production: Evidence from Zambia. Climate Research, 79, 39-53.

[42] Akinbile, C.O., Abd El-Latif, K.M., Abdullah, R. and Yusoff, M.S. (2020) Rice Production and Water Use Efficiency for Self-Sufficiency in Malaysia: A Review. Trends in Applied Sciences Research, 6, 1127-1140. https://doi.org/10.3923/tasr.2011.1127.1140

[43] Namara, R.E., Hanjra, M.A., Castillo, G.E., Ravnborg, H.M., Smith, L. and Van Koppen, B. (2019) Agricultural Water Management and Poverty Linkages. Agricultural Water Management, 97, 520-527. https://doi.org/10.1016/j.agwat.2009.05.007

[44] MLA Drake, E. (2018) Water Stress and Conflict Severity: A Study on How Environmental Changes Affect Conflicts in Africa. https://doi.org/10.17615/fnxa-9w69

[45] Cooper, P.J.M., Dimes, J., Rao, K.P.C., Shapiro, B., Shiferaw, B. and Twomlow, S. (2018) Coping Better with Current Climatic Variability in the Rain-Fed Farming Systems of Sub-Saharan Africa: An Essential First Step in Adapting to Future Climate Change? Agriculture, Ecosystems \& Environment, 126, 24-35. https://doi.org/10.1016/j.agee.2008.01.007

[46] Rockström, J. and Barron, J. (2020) Water Productivity in Rain Fed Systems: Overview of Challenges and Analysis of Opportunities in Water Scarcity Prone Savannahs. Irrigation Science, 25, 299-311. https://doi.org/10.1007/s00271-007-0062-3

[47] Wiggins, S., Kirsten, J. and Llambí, L. (2020) The Future of Small Farms. World Development, 38, 1341-1348. https://doi.org/10.1016/j.worlddev.2009.06.013

[48] Abugri, B., Ahenkan, A. and Bawole, J.N. (2010) The Role of Knowledge Management in National Food and Agriculture Policy Implementation: Evidence from the 
Planting for Food and Jobs Agricultural Policy of Ghana. International Journal of Innovative Science and Research Technology. https://www.ijisrt.com/

[49] Ragasa, C., Lambrecht, I. and Kufoalor, D.S. (2018) Limitations of Contract Farming as a Pro-Poor Strategy: The Case of Maize out Grower Schemes in Upper West Ghana. World Development, 102, 30-56.

https://doi.org/10.1016/j.worlddev.2017.09.008 